\title{
Characterization of Kenyan Ceramics for Production of Medium Duty Alumina Firebrick Incinerator Linings
}

\author{
1,2MAKOKHA, JW; ${ }^{1} *$ KARIUKI, DK; ${ }^{2}$ MWITARI, PG \\ ${ }^{1}$ Department of Chemistry, University of Nairobi, P.O.Box 30917-00100, Nairobi \\ ${ }^{2}$ Chemical Engineering Division, Kenya Industrial Dresearch Development Institute, P.O. Box 30650-00100, Nairobi, Kenya \\ *Corresponding Author Email: kkariuki@uonbi.ac.ke
}

\begin{abstract}
The aim of this study was to evaluate locally available ceramic raw materials for the manufacture of Medium Duty Alumina Refractory Firebrick for incinerator lining.The clays were collected from two sites, Eburru in Nakuru County and Mukurwe-ini in Nyeri County in Kenya. Atomic Absorption Spectrophotometer and X-Ray Diffraction analytical methods were used to determine the chemical composition of the respective clays before and after firing at $1000^{\circ} \mathrm{C}$ for two hours.Atomic Absorption Spectrophotometer results revealed that Eburru Kaolin contained the highest amount of silica at $72.64 \% \mathrm{SiO}_{2}$ but had the lowest of all other oxides. All the three raw materials were found to increase their oxide percentages after firing due to the loss in moisture and organic matter and reflected on their aluminasilica ratio. The X-Ray Diffraction results showed that the refractory formulated using the clays at a ratio of 2:2:1 Eburru Kaolin : Eburru Fireclay: Mukuruweini Ballclay attained good structural properties after firing at $1000^{\circ} \mathrm{C}$ for two hours and was comparable to commercial products in the market in addition to meeting the standards of a Medium Duty Refractory Firebrick.This is suitable for manufacture of incinerator linings.
\end{abstract}

\section{DOI: https://dx.doi.org/10.4314/jasem.v22i10.01}

Copyright: Copyright $\odot 2018$ Makokha et al. This is an open access article distributed under the Creative Commons Attribution License (CCL), which permits unrestricted use, distribution, and reproduction in any medium, provided the original work is properly cited.

Dates: Received: 09 September 2018; Revised: 22 October: 2018; Accepted: 30 October 2018

Keywords:Incinerator linings,Kaolin, Firebrick, Refractory

Refractory firebricks are ceramic materials that withstand high temperatures while maintaining their structural properties as well as resist destructive influences such as abrasion, rapid changes in temperature and pressure, corrosion by slags and fluxes, erosion by molten slags (Chlup et al,2006). They are also expected to withstand load at service conditions, resist contamination of the material with which it comes into contact, maintain sufficient dimensional stability at high temperature after or during repeated thermal cycling, and conserve heat (Chukwudu, 2008).Principally, they are composed of aluminium silicate.. Refractories are employed in great quantities in the metallurgical, glassmaking, and ceramics industries, where they are molded into a variety of shapes to line the interiors of furnaces, kilns, and other devices that process materials at very high temperatures (Sani et al, 2011). The high strengths exhibited by primary chemical bondsin refractory materials, enable most of them to possess unusually good combinations of high melting point and chemical inertness (Gusteve and Christian, 2017). Clay based refractories are the fireclay materials and are made from clays containing the aluminosilicate mineralkaolinite $\left(\mathrm{Al}_{2}\left[\mathrm{Si}_{2} \mathrm{O}_{5}\right][\mathrm{OH}]_{4}\right)$ plus impurities such as alkalis and iron oxides. The alumina $\left(\mathrm{Al}_{2} \mathrm{O}_{3}\right)$ content ranges from 25 to 45 percent (Chukwudu, 2008). Refractories are classified based on the impurity content and the alumina-to-silica ratio $\left(\mathrm{Al}_{2} \mathrm{O}_{3} / \mathrm{SiO}_{2}\right)$.

Refractory firebricks are crucial and play a vital role in industrial development of any nation. Currently, Kenya spends approximately Kenya Shillings 3 billion annually to import refractories mostly from India and China for its manufacturing sector despite availability of raw materials and technology advancement, to sustain its manufacturing industrial sector (KIPPRA, 2013). According to Central Bureau of Statistics report of 2014, , Kenya has a potential of cutting down firebricks imports to $20 \%$ and increase exports by 15 $\%$ in 10 years (Makokha, 2015).

The main consumers of the firebricks are cement and extractive industries which are on the rise. In general the demand of refractory firebricks is bound to increase tremendously owing to the increased growth of Kenya's manufacturing sector (World Bank, 2013). The boom in the building and construction industry in Kenya has led to increased volume of utilization of cement, leading to high number of new cement manufacturing factories and consequently increasing demand on firebricks.

*Corresponding Author Email: kkariuki@uonbi.ac.ke 
The principal raw materials used in the production of firebricks are clay rich in $\mathrm{Al}_{2} \mathrm{O}_{3}-\mathrm{SiO}_{2}$ which are naturally available.Practically, a range of raw materials are utilized to achieve desirable chemical composition of the firebricks (Harbison, 2005). These raw materials are locally available. Kaolin and fireclay are found in Nakuru County at Eburru hills, Gilgil Sub-county, while the ball clay is found in Nyeri County, Mukurwe-ini sub-county. There has been limited economical utilization of these raw materials and the clays do not sustain agricultural activities.

\section{MATERIALS AND METHODS}

Sampling: Eburru Kaolin and Eburru Fireclay were sampled from Nakuru County, Eburru location while Mukurweini Ball Clay was sampled from Nyeri County, Rutune location. Samples were collected using clean plastic hoes in the quarry at a depth of $5 \mathrm{~cm}$ to $100 \mathrm{~cm}$ below surface thenlabelled EK, EF, MBC and transported to KIRDI laboratory for analysis.In the laboratory the clays were crushed, grounded, sieved, weighed and stored at room temperature in the laboratory.

Atomic Absorption Spectrophotometric Analysis: The chemical composition of the EK, EF and MBC raw clay sample in percentage weight of $\left(\mathrm{SiO}_{2}, \mathrm{Al}_{2} \mathrm{O}_{3}\right.$, $\mathrm{Fe}_{2} \mathrm{O}_{3}, \mathrm{Na}_{2} \mathrm{O}, \mathrm{K}_{2} \mathrm{O}$ ) was determine by analysing for variuos metal elements using Varian Spectra AA-10 Model Five milligrams of sample was weighed and digested using Hydroflouric acid and standardized using Sodium Borohydrate (Varian, 1979). The analyte was then diluted to $50 \mathrm{~cm}^{3}$ and set for analysis in the AAS. Another set samples was first fired in a furnace at $1000^{\circ} \mathrm{C}$ and analyzed in the AAS to determine the firing effect on alumina and silica compositions.

The metal concentrations were obtained after correction with the blank. The initial concentration of metal in each sample resulted to various dilution factors; the quantities of metals in each sample was expressed as $\mathrm{mg} / \mathrm{g}$.
Loss On Ignition: The organic and water content percentage, of the raw materials were determined by measuring the weight loss of a known mass of the sample after firing in a furnace at $1000^{\circ} \mathrm{C}$ for one hour thirty minutes.

\section{RESULTS AND DISCUSSIONS}

AAS analysis results on of EK, EF and MBCas described are as shown in Table 1. The Silica content of Eburru Kaolin was found to be the highest at $72.4 \%$ $\mathrm{SiO}_{2}$, though it recorded the least content of all the other oxides. The percentage elemental oxides of all samples was found to increase upon firing at $1000^{\circ} \mathrm{C}$ due to loss of organic matter, moisture and water of crystalization across all of the raw materials. This was reflected in a slight increase of the alumina-silica ratio in $\mathrm{EK}$ and $\mathrm{MBC}$.The alumina-silica ratio of $\mathrm{EF}$ and MBC of 0.40 and 0.68 respectively were within the range $0.37-0.60$ while that of EK was below the standard limit for production of a medium duty refractory firebrick. The percentage of $\mathrm{Fe}_{2} \mathrm{O}_{3}$ content of $\mathrm{EF}, 3.01$ and $\mathrm{MBC}, 4.03$, were above the required maximum of $2.50 \%$ while that of EK, 0.99, was within the required limit of $0-2.50$ wt $\% \mathrm{Fe}_{2} \mathrm{O}_{3}$. Eburru Kaolin, Eburru Fireclay and Mukurweini Ball Clay were mixed in the ratio $2: 2: 1$ to obtain a formulation with desirable chemical composition as shown in Table 2.The Medium Duty Refractory Firebrick (MDRF) was found to have a comparative chemical compostion as commercial imported refractories and within the prescribed standards of a medium duty firebrick.

Figure 1 shows the MDRF, XRD diffractogram while Figure 2 shows diffractogram of the MDRF after firing at $1000^{\circ} \mathrm{C}$. In Figure 1 , there is presence of kaolinite and quartz while in Figure 2 there is presence of mullite, quartz, cristobalite and absence of kaolinite. At $1000{ }^{\circ} \mathrm{C}$ temperatures firing, kaolinite transforms to mullite while part of quartz transforms to cristobalite. The peak intensity of quartz in the fired raw materials was low compared to the peak intensity in the raw material samples.

\begin{tabular}{|c|c|c|c|c|c|c|}
\hline \multirow[t]{2}{*}{ Constituent } & \multicolumn{2}{|l|}{ EK } & \multicolumn{2}{|l|}{ EF } & \multicolumn{2}{|l|}{ MBC } \\
\hline & EK $^{1}$ & $\mathbf{E K}^{2}$ & $\mathbf{E F}^{1}$ & $\mathbf{E F}^{2}$ & MBC $^{1}$ & $\mathrm{MBC}^{2}$ \\
\hline$\% \mathrm{SiO}_{2}$ & 72.64 & 73.11 & 66.64 & 68.01 & 55.38 & 57.01 \\
\hline$\% \mathrm{Al}_{2} \mathrm{O}_{3}$ & 24.74 & 26.01 & 26.63 & 27.41 & 36.85 & 38.99 \\
\hline$\% \mathrm{Fe}_{2} \mathrm{O}_{3}$ & 0.71 & 0.99 & 02.78 & 3.01 & 3.86 & 4.03 \\
\hline$\% \mathrm{~K}_{2} \mathrm{O}$ & 0.05 & 0.08 & 0.19 & 0.27 & 1.14 & 1.61 \\
\hline$\% \mathrm{Na}_{2} \mathrm{O}$ & 0.13 & 0.23 & 0.17 & 0.22 & 0.43 & 0.57 \\
\hline$\% \mathrm{TiO}_{2}$ & 0.73 & 0.11 & 2.25 & 2.87 & 2.96 & 3.10 \\
\hline LOI & 7.83 & $<0.01$ & 9.86 & $<0.01$ & 14.79 & $<0.01$ \\
\hline $\mathrm{Al}_{2} \mathrm{O}_{3} / \mathrm{SiO}_{2}$ ratio & 0.34 & 0.36 & 0.40 & 0.40 & 0.67 & 0.68 \\
\hline
\end{tabular}

MAKOKHA, JW; KARIUKI, DK; MWITARI, PG 
Table 2: Chemical Composition Analysis of Sample Firebrick Formulation

\begin{tabular}{llll}
\hline Elemental Oxide & Standard & Imported & Sample Firebricks $\mathrm{STO}_{3}$ \\
\hline$\% \mathrm{Al}_{2} \mathrm{O}_{3}$ & $26-36$ & 33.80 & 27.53 \\
$\% \mathrm{SiO}_{2}$ & $60-70$ & 57.69 & 65.87 \\
$\% \mathrm{TiO}_{2}$ & $\leq 4$ & 2.26 & 3.43 \\
$\% \mathrm{Fe}_{2} \mathrm{O}_{3}$ & $\leq 2.5$ & 1.94 & 2.08 \\
$\% \mathrm{CaO}$ & $\leq 1.0$ & 0.55 & 0.11 \\
$\% \mathrm{~K}_{2} \mathrm{O}$ & $\leq 3$ & 1.20 & 0.12 \\
$\% \mathrm{Na}_{2} \mathrm{O}$ & - & 0.23 & 0.07 \\
$\% \mathrm{MgO}$ & - & 0.31 & 0.18 \\
$\% \mathrm{MnO}$ & - & 0.02 & 0.12 \\
$\mathrm{Al}_{2} \mathrm{O}_{3} / \mathrm{SiO}_{2}$ ratio & $\leq 0.60-0.37 \geq$ & 0.59 & 0.42 \\
\hline
\end{tabular}

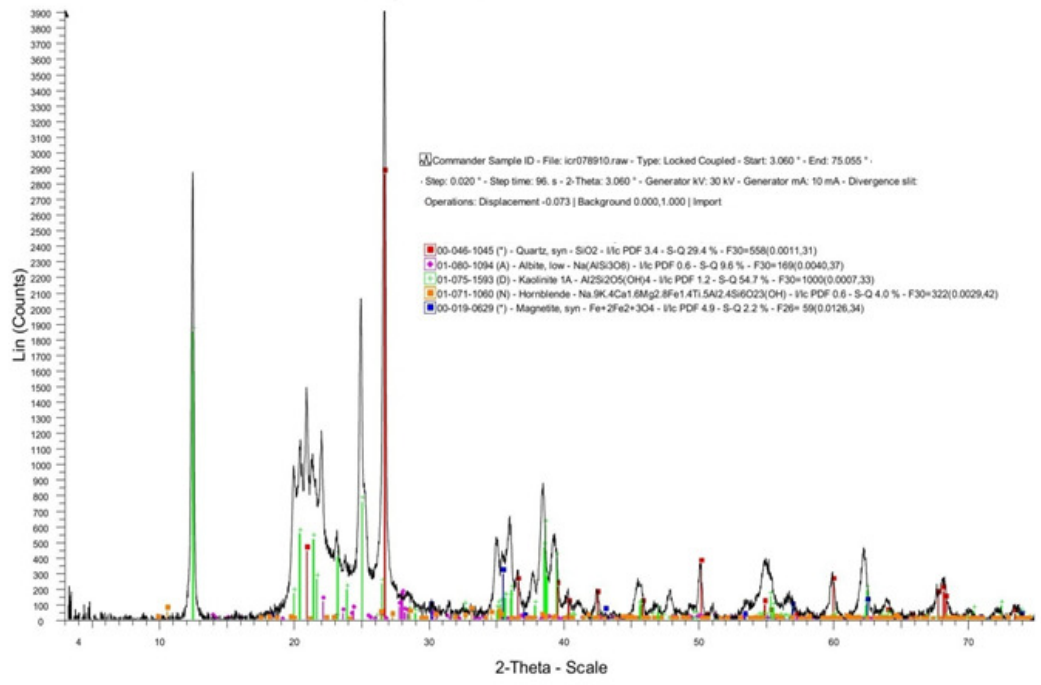

Fig1: Difractogram of the Sample of the MDRF before firing

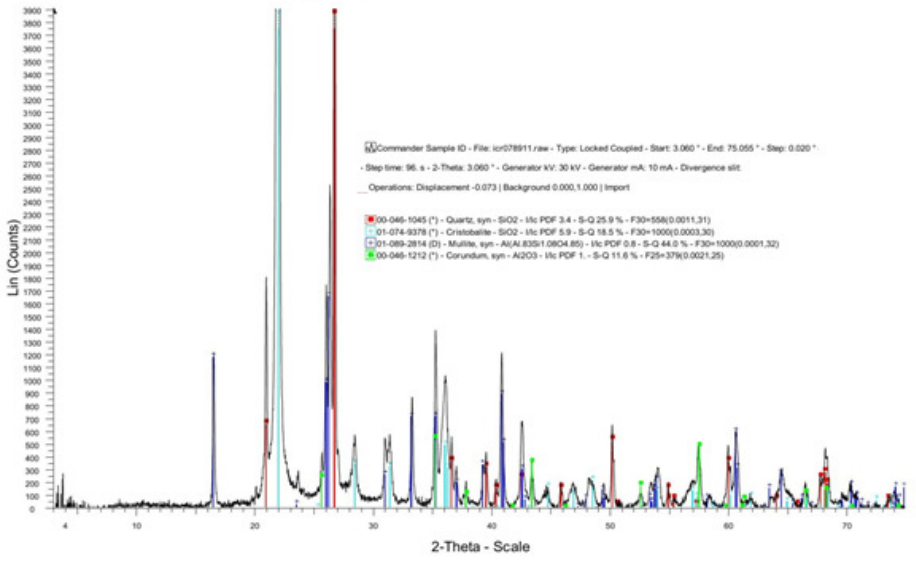

Fig2: Diffractogram of the Sample of MDRF after firing at $1000^{\circ} \mathrm{C}$ for two hours

The 2-Theta picks dipicting the crystallography of the kaolinite only shifted slightly to the right but generally retaining the structural pattern hence the structural integrity of the constituents of theraw materials. The formulated refractory firebrick samples was found to retain its structural property after firing it at $1000^{\circ} \mathrm{C}$ for two hours.

Conclusion:The ceramic raw materials, Eburru Kaolin, Eburru Fireclay and Mukuruweini Ball clays were found to be of suitable quality for the formulation 
and manufacture of Medium Duty Refractory Firebricks.The MDRF sample was found to meet the quality standards, and was comparable to the commercial MDRFs in the market. The MDRFs are suitable for the production of incinerator linings in refractories. .

Acknowledgement: The authors would like to acknowledge the Kenya Industrial Research and Development Institute (KIRDI) for the scholarship and availing laboratory equipment for the study.

\section{REFERENCES}

Chlup Z; Boccaccini DN; Leonelli C; Romagnoli M; Boccaccini AR (2006). Fracture Behaviour of Refractory Ceramics after Cyclic Thermal Shock, Ceramics Silikáty 50 (4) 245-250.

Chukwudu, BC (2008). Characterization and Evaluation of the Refractory Properties of the Nsu Clay Deposit in Imo State Nigeria. Pacific Journal of Science and Technology, Abuja, 487494.

Gustave KD; Christian D (2017). Characterization and Applications of Kaolinite Robustly Grafted by an Ionic Liquid with Naphthyl Functionality Materials 10, 1006.
Harbison-Walker (2005). Handbook of Refractory Practice; Moon Township, Pennsylvania; volume 5; 1-89

Kenya Institute of Public Policy and Research Analysis, (KIPPRA) (2013).Kenya Economic Report, Creating Enabling Environment for Stimulating Investment for Competitive and Sustainable Counties.

Makokha JW (2015). Utilization of Kwale Ilmenite Ore in the Production of Refractory Fireclay Bricks.MSc. Thesis, University of Nairobi

Sani E; Mercatelli L; Francini F; Sans J-L; Sciti D (2011). Ultra-Refractory Ceramics for highTemperature Solar Absorbers. Scripta Materialia Vol. 65 pp.775-778 (2011)

Varian (1979). Analytical Methods for Flame Spectroscopy; Varian Techtron Pty Ltd; Springvale Australia.

World Bank (2013). Kenya Economic Update; accelerating growth and poverty reduction in new Kenya; Poverty reduction and Economic Management Unit Africa Region; Edition 8. 